\title{
26. INTERSTITIAL WATER CHEMISTRY: DEEP SEA DRILLING PROJECT, LEG $6^{1}$
}

\author{
B. J. Presley and I. R. Kaplan \\ Department of Geology and Institute of Geophysics, and Planetary Physics, \\ University of California, Los Angeles, California
}

\section{INTRODUCTION}

The interstitial water received at UCLA from Leg 6 (Hawaii to Guam) consisted of forty-nine samples of approximately 5 milliliters each, four samples of approximately 100 milliliters each, and four samples of approximately 10 milliliters each. These pore waters had been squeezed from sediment consisting primarily of biogenic oozes and volcanic ash, and had been collected at fourteen sites in the NW Pacific Ocean and Phillipine Seas. All samples were filtered through a 0.45 -micron filter immediately after collection. The 5 -milliliter samples were sealed in plastic syringes on board ship by heat sealing the tip and pouring RTV silicon rubber around the plunger. These and the large samples, stored in polyethylene bottles, were refrigerated except for the time in shipment to UCLA from SIO. The four 10-milliliter samples were frozen in polyethylene bottles on board ship and were kept frozen until analysis had begun.

Analysis was started as soon as the samples had arrived at UCLA, nevertheless, as much as three months had then elapsed after collection.

\section{EXPERIMENTAL PROCEDURES}

The experimental procedures used are essentially the same as those briefly outlined in the Leg 5 report (Presley et al.), but some modifications were made in an attempt to obtain more reliable data. As has been noted in previous leg reports, the small size of the samples leads to considerable analytical difficulty when data for many constituents are desired. The authors nevertheless believe that using the methods that have been developed in the course of this work they can obtain reliable concentrations for at least ten elements, sulfate and total dissolved carbonate (as well as $\mathrm{S}^{34} / \mathrm{S}^{32}$ and $\mathrm{C}^{13} / \mathrm{C}^{12}$ ratios) using only 5 milliliters of sample. Detailed experimental procedures are described elsewhere in this volume.

\footnotetext{
${ }^{1}$ Publication No. 853, Institute of Geophysics and Planetary
}

\section{RESULTS AND DISCUSSION}

The data obtained from the 5 milliliter samples are presented in Table 1, but major cation concentrations have been omitted from this report because these can be found in the report by Manheim et al. (this volume). The authors' data for these cations agree reasonably well with those of Manheim, with a few notable exceptions. Data obtained from the 100 milliliters and the frozen samples can be found in Table 2 .

The trace metals iron, cobalt, nickel and copper can only be determined on relatively large volume samples by present techniques, and these samples are limited in number to four on each leg by a directive from the JOIDES Interstitial Water Panel. The four samples from Leg 6 showed somewhat higher concentrations of iron, cobalt and copper than were typical of previous Pacific samples (Leg 5), but similar nickel concentration. The values are also generally higher than those found in the Atlantic samples (Presley and Kaplan, Leg 4 report), and are higher than those characteristic of oxidizing sediments collected by piston coring (Brooks et al., 1967).

The iron, cobalt and copper concentrations show less variation than values obtained previously. This could be due to the more uniform lithology of the Leg 6 sediments, but the small number of samples available makes any generalization difficult. It does, however, appear that biogenic oozes yield pore waters somewhat enriched in these trace metals, when compared to terrigenous-derived sediments.

The silicon values given in Table 2 are similar to those determined on previous samples, falling between saturation with respect to quartz and saturation with respect to amorphous silica. A few samples from previous legs have more closely approached saturation with respect to amorphous silica than any of the present samples do, despite the high volcanic glass content of some of these, especially those at Site 53. Manheim's silicon data for this and other sites also seem to indicate undersaturation with respect to amorphous silica. Apparently here, and in most places, dissolved silica is taken up in forming authigenic silicate minerals, preventing a buildup to saturation with amorphous silica. 
TABLE 1

Interstitial Water Chemistry, Leg 6

\begin{tabular}{|c|c|c|c|c|c|c|c|c|c|c|c|}
\hline $\begin{array}{c}\text { Sample }^{\mathrm{a}} \\
\text { Designation }\end{array}$ & $\underset{(\mathrm{m})}{\text { Depth }^{\mathrm{b}}}$ & Age & Description & $\underset{(\mathrm{g} / \mathrm{kg})}{\mathrm{Cl}}$ & $\underset{(\mathrm{mg} / \mathrm{kg})}{\mathrm{Br}}$ & $\underset{(\mathrm{mg} / \mathrm{kg})}{\mathrm{B}}$ & $\underset{(\mu \mathrm{gn} / \mathrm{kg})}{\mathrm{Mn}}$ & $\begin{array}{c}\mathrm{Zn} \\
(\mu \mathrm{g} / \mathrm{kg})\end{array}$ & $\underset{(\mu \mathrm{g} / \mathrm{kg})}{\mathrm{Li}}$ & $\begin{array}{c}\text { Total } \\
\mathrm{CO}_{2} \\
(\mathrm{~mm} / \mathrm{kg})\end{array}$ & $\begin{array}{c}\operatorname{Total}^{\mathrm{c}} \\
\mathrm{CO}_{2} \\
(\mathrm{~mm} / \mathrm{kg})\end{array}$ \\
\hline $45.1-1-1$ & 3 & Unknown & $\begin{array}{l}\text { Brown zeolitic clay, } 5 \% \text { ferric } \\
\text { oxide }\end{array}$ & 19.2 & 62 & 7.0 & 100 & 545 & 200 & 2.89 & - \\
\hline $47.0-1-3$ & 4 & Pleistocene & $\begin{array}{l}\text { Layered gray-yellow-brown } \\
\text { foraminiferal-nannoplankton } \\
\text { ooze }\end{array}$ & 19.0 & 70 & 4.8 & 870 & 660 & 176 & 2.91 & 2.24 \\
\hline $47.2-2-3$ & 22 & Lower Pleistocene & $\begin{array}{l}\text { Nannoplankton-foraminiferal } \\
\text { ooze, 25\% volcanic ash }\end{array}$ & 19.4 & 65 & 3.6 & 340 & 585 & 156 & 2.16 & 2.01 \\
\hline $47.2-4-3$ & 40 & Upper Pliocene & $\begin{array}{l}\text { Nannoplankton-foraminiferal } \\
\text { ooze, } 5-10 \% \text { glass }\end{array}$ & 19.6 & - & 3.5 & 430 & 900 & 171 & 2.12 & - \\
\hline $47.2-7-1$ & 64 & Lower Eocene & $\begin{array}{l}\text { Nannoplankton-foraminiferal } \\
\text { ooze }\end{array}$ & 19.7 & 64 & 4.3 & 440 & 840 & 156 & 3.21 & 1.94 \\
\hline $47.2-10-2$ & 93 & Lower Paleocene & $\begin{array}{l}\text { Nannoplankton-foraminiferal } \\
\text { ooze }\end{array}$ & 19.5 & - & 4.1 & 175 & 1170 & 161 & 4.09 & 2.10 \\
\hline $48.2-1-2$ & 54 & $\begin{array}{l}\text { Lower Pliocene- } \\
\text { Upper Miocene }\end{array}$ & Nannoplankton chalk ooze & 19.7 & 69 & 3.3 & 245 & 600 & 161 & 1.56 & 0.94 \\
\hline $49.0-1-2$ & 3 & Pleistocene & Brown mud, up to $20 \%$ glass & 19.4 & - & 3.6 & $<50$ & 540 & 185 & 2.87 & 1.94 \\
\hline $49.1-1-3$ & 7 & Cretaceous (?) & $\begin{array}{l}\text { Brown zeolitic mud, manganese } \\
\text { nodule, limonite }\end{array}$ & 19.3 & 71 & 4.9 & 105 & 440 & 200 & 3.29 & 2.18 \\
\hline $50.1-1-4$ & 9 & Pleistocene & $\begin{array}{l}\text { Light yellow-brown nannoplank- } \\
\text { ton clay, siliceous fossils, } 20 \%\end{array}$ & 19.1 & - & 2.1 & 210 & 530 & 180 & 2.58 & 2.44 \\
\hline $50.1-3-5$ & 30 & Unknown & $\begin{array}{l}\text { Dark yellow zeolitic clay, } 20 \% \\
\text { limonite }\end{array}$ & 19.4 & 69 & 5.0 & $<50$ & 560 & 200 & 2.97 & 1.98 \\
\hline $51.1-1-5$ & 25 & Pleistocene & $\begin{array}{l}\text { Gray-brown sandy diatom- } \\
\text { radiolarian volcanic mud }\end{array}$ & 19.4 & 75 & 2.2 & 9415 & 320 & 176 & 1.85 & 1.91 \\
\hline $51.0-1-4$ & 120 & Miocene & $\begin{array}{l}\text { "Drilling breccia" fragments, } \\
\text { zeolitic clay }\end{array}$ & 19.1 & - & 6.8 & 215 & 1070 & 234 & 1.37 & 2.04 \\
\hline $52.0-1-4$ & 6 & Unknown & $\begin{array}{l}\text { Brown ashey clay, } 20 \% \text { glass, } \\
5 \% \text { zeolite }\end{array}$ & 19.7 & - & 3.2 & 215 & 845 & 171 & 2.21 & 1.70 \\
\hline $52.0-3-2$ & 20 & Unknown & $\begin{array}{l}\text { Light red-brown clay, } 8 \% \text { glass, } \\
4 \% \text { zeolite }\end{array}$ & 19.1 & 62 & 3.4 & 4085 & 680 & 180 & - & 1.77 \\
\hline $52.0-5-3$ & 40 & Unknown & $\begin{array}{l}\text { Dark gray-brown clay, } 20 \% \text { glass, } \\
5 \% \text { zeolite }\end{array}$ & 19.2 & 75 & 6.1 & 370 & 490 & 195 & 2.96 & 1.57 \\
\hline $53.1-1-4$ & 6 & Unknown & $\begin{array}{l}\text { Dark yellow-brown zeolitic clay, } \\
\text { limonite, etc., } 10 \%\end{array}$ & 19.3 & - & 6.7 & 100 & 575 & 215 & 1.71 & 1.54 \\
\hline
\end{tabular}


TABLE 1 - Continued

\begin{tabular}{|c|c|c|c|c|c|c|c|c|c|c|c|}
\hline $\begin{array}{c}\text { Sample }^{\mathrm{a}} \\
\text { Designation }\end{array}$ & $\begin{array}{l}\text { Depth }^{b} \\
\text { (m) }\end{array}$ & Age & Description & $\underset{(\mathrm{g} / \mathrm{kg})}{\mathrm{Cl}}$ & $\begin{array}{c}\mathrm{Br} \\
(\mathrm{mg} / \mathrm{kg})\end{array}$ & $\begin{array}{c}\mathrm{B} \\
(\mathrm{mg} / \mathrm{kg})\end{array}$ & $\underset{(\mu \mathrm{g} / \mathrm{kg})}{\mathrm{Mn}}$ & $\underset{(\mu \mathrm{g} / \mathrm{kg})}{\mathrm{Zn}}$ & $\begin{array}{c}\mathrm{Li} \\
(\mu \mathrm{g} / \mathrm{kg})\end{array}$ & $\begin{array}{c}\text { Total } \\
\mathrm{CO}_{2} \\
(\mathrm{~mm} / \mathrm{kg})\end{array}$ & $\begin{array}{c}\text { Total }^{\mathrm{c}} \\
\mathrm{CO}_{2} \\
(\mathrm{~mm} / \mathrm{kg})\end{array}$ \\
\hline $53.2-1-4$ & 18 & Upper Miocene & $\begin{array}{l}\text { Brown radiolarian silt and } \\
\text { volcanic glass }\end{array}$ & 19.7 & 70 & 4.8 & 2800 & 560 & 268 & 1.24 & 0.61 \\
\hline $53.1-2-5$ & 28 & Upper Miocene & $\begin{array}{l}\text { Dark gray-brown sandy-to-clayey } \\
\text { ash, with Radiolaria }\end{array}$ & 20.0 & - & 4.3 & 4225 & 605 & 224 & - & 0.77 \\
\hline $53 \cdot 1-3-4$ & 60 & $\begin{array}{l}\text { Middle to Upper } \\
\text { Miocene }\end{array}$ & Gray silty-to-clayey volcanic ash & 19.4 & 75 & 4.9 & 2100 & 590 & 185 & 0.63 & 0.23 \\
\hline $53.0-1-2$ & 102 & Upper Middle Miocene & Firm gray sandy-silty volcanic ash & 19.7 & - & 1.7 & 775 & 240 & 195 & 0.46 & 0.25 \\
\hline $53.0-3-1$ & 137 & $\begin{array}{l}\text { Lower to Middle } \\
\text { Miocene }\end{array}$ & Gray to black silty-to-muddy ash & 19.3 & - & 1.4 & 320 & 240 & 220 & - & 0.33 \\
\hline $53.0-4-1$ & 166 & $\begin{array}{l}\text { Lower Oligocene to } \\
\text { Lower Miocene }\end{array}$ & Red to black silty-to-muddy ash & 19.8 & - & 1.5 & 270 & 610 & 325 & - & 0.33 \\
\hline $53.0-6-2$ & 195 & $\begin{array}{l}\text { Lower Oligocene to } \\
\text { Lower Miocene }\end{array}$ & $\begin{array}{l}\text { Hard gray-green volcanic rock } \\
\text { chalk }\end{array}$ & 19.4 & 69 & 5.5 & 180 & 575 & 365 & 0.43 & 0.30 \\
\hline $54.0-2-3$ & 142 & Lower Middle Miocene & $\begin{array}{l}\text { Gray calcareous sandy volcanic } \\
\text { ash }\end{array}$ & 19.1 & - & 3.2 & 725 & 295 & 107 & 1.16 & 0.54 \\
\hline $54.0-4-2$ & 206 & Lower Middle Miocene & $\begin{array}{l}\text { Very firm gray calcareous sandy } \\
\text { volcanic ash }\end{array}$ & - & 71 & 2.3 & 620 & 250 & 122 & 1.37 & 0.47 \\
\hline $54.0-6-4$ & 227 & Lower Middle Miocene & Firm gray calcareous silty ash & 19.3 & 67 & 3.0 & 530 & 300 & 122 & 1.03 & 0.44 \\
\hline $54.0-7-2$ & 264 & Lower Middle Miocene & $\begin{array}{l}\text { Dark gray-brown silty calcareous } \\
\text { ash }\end{array}$ & 19.4 & - & 3.6 & 320 & 535 & 137 & 2.90 & 1.70 \\
\hline $55.0-1-3$ & 4 & Pleistocene & $\begin{array}{l}\text { Light brown nannoplankton- } \\
\text { foraminiferal ooze }\end{array}$ & 19.1 & 63 & 4.7 & $<75$ & 455 & 171 & 3.55 & 1.80 \\
\hline $55.0-3-3$ & 22 & Upper Pliocene & $\begin{array}{l}\text { Light foraminiferal- } \\
\text { nannoplankton ooze }\end{array}$ & 19.3 & 70 & 4.0 & $<75$ & 550 & 166 & 3.16 & 2.15 \\
\hline $55.0-5-3$ & 40 & Lower Upper Miocene & $\begin{array}{l}\text { Nannoplankton ooze, } 90 \% \\
\text { discoaster }\end{array}$ & 19.7 & - & 4.7 & $<75$ & 290 & 166 & 2.85 & 2.31 \\
\hline $55.0-7-3$ & 58 & Lower Middle Miocene & $\begin{array}{l}\text { White nannoplankton- } \\
\text { foraminiferal ooze }\end{array}$ & 18.9 & 70 & 3.8 & $<75$ & 300 & 195 & 2.84 & 2.15 \\
\hline $55.0-10-3$ & 85 & Lower Miocene & $\begin{array}{l}\text { Light brown nannoplankton } \\
\text { radiolarian-foraminiferal ooze }\end{array}$ & - & 67 & 3.3 & $<75$ & 320 & 156 & 1.85 & 2.10 \\
\hline $55.0-12-3$ & 106 & $\begin{array}{l}\text { Upper Oligocene to } \\
\text { Lower Miocene }\end{array}$ & $\begin{array}{l}\text { White nannoplankton ooze, } \\
\text { Radiolaria, foraminifera }\end{array}$ & 19.6 & - & 4.1 & $<75$ & 875 & 161 & 2.51 & 2.10 \\
\hline $56.2-1-6$ & 82 & Upper Miocene & $\begin{array}{l}\text { White nannoplankton- } \\
\text { foraminiferal ooze }\end{array}$ & 19.1 & 62 & 4.4 & $<75$ & 880 & 151 & 3.62 & 2.21 \\
\hline $56.2-4-4$ & 106 & Middle Miocene & $\begin{array}{l}\text { White nannoplankton- } \\
\text { foraminiferal ooze }\end{array}$ & 19.1 & 66 & 3.9 & $<75$ & 505 & 146 & - & 2.15 \\
\hline
\end{tabular}




\begin{tabular}{|c|c|c|c|c|c|c|c|c|c|c|c|}
\hline $\begin{array}{c}\text { Sample }^{\mathrm{a}} \\
\text { Designation }\end{array}$ & $\begin{array}{c}\text { Depth }^{b} \\
\text { (m) }\end{array}$ & Age & Description & $\underset{(\mathrm{g} / \mathrm{kg})}{\mathrm{Cl}}$ & $\begin{array}{c}\mathrm{Br} \\
(\mathrm{mg} / \mathrm{kg})\end{array}$ & $\underset{(\mathrm{mg} / \mathrm{kg})}{\mathrm{B}}$ & $\underset{(\mu \mathrm{g} / \mathrm{kg})}{\mathrm{Mn}}$ & $\underset{(\mu \mathrm{g} / \mathrm{kg})}{\mathrm{Zn}}$ & $\begin{array}{c}\mathrm{Li} \\
(\mu \mathrm{g} / \mathrm{kg})\end{array}$ & $\begin{array}{c}\text { Total } \\
\mathrm{CO}_{2} \\
(\mathrm{~mm} / \mathrm{kg})\end{array}$ & $\begin{array}{c}\text { Total }^{\mathrm{c}} \\
\mathrm{CO}_{2} \\
(\mathrm{~mm} / \mathrm{kg})\end{array}$ \\
\hline $56.2-6-4$ & 193 & $\begin{array}{l}\text { Lower Miocene- } \\
\text { Upper Oligocene }\end{array}$ & $\begin{array}{l}\text { White nannoplankton- } \\
\text { foraminiferal ooze }\end{array}$ & 19.8 & 63 & 2.6 & 100 & 475 & 151 & 3.39 & 2.15 \\
\hline $56.2-8-4$ & 212 & Upper Oligocene & $\begin{array}{l}\text { White nannoplankton- } \\
\text { foraminiferal ooze, yellow bands }\end{array}$ & 19.2 & - & 1.2 & 75 & 675 & 180 & 2.83 & 1.94 \\
\hline $56.2-10-4$ & 229 & Upper Oligocene & $\begin{array}{l}\text { Mottled brown-white silty } \\
\text { foraminiferal sand, ash }\end{array}$ & 19.4 & 68 & 4.5 & 75 & 260 & 146 & 3.22 & 2.33 \\
\hline $57.2-1-1$ & 10 & Upper Pliocene & White nannoplankton chalk ooze & 19.7 & 65 & 3.8 & 115 & 1070 & 166 & 1.54 & 1.37 \\
\hline $57.1-1-4$ & 50 & Upper Miocene & White nannoplankton chalk ooze & 19.2 & - & 4.2 & 110 & 550 & 161 & 2.32 & 1.24 \\
\hline $57.0-1-1$ & 299 & Upper Oligocene & $\begin{array}{l}\text { Mixed gray-yellow-green } \\
\text { nannoplankton marl }\end{array}$ & 19.5 & 68 & 2.3 & $<75$ & 300 & 127 & 1.08 & 0.23 \\
\hline $57.1-2-2$ & 309 & Upper Oligocene & Light blue-green banded chalk & 19.2 & 67 & 3.0 & 160 & 200 & 127 & 1.26 & 0.30 \\
\hline $57.1-4-4$ & 326 & Upper Oligocene & $\begin{array}{l}\text { Nannoplankton ooze with ash } \\
\text { bands }\end{array}$ & 19.3 & - & 2.3 & 335 & 300 & 132 & 1.00 & - \\
\hline $58.1-1-2$ & 3 & Pleistocene & Light brown silty chalk ooze & 19.3 & 67 & 4.6 & 105 & 500 & 245 & 3.32 & 1.67 \\
\hline $58.2-1-3$ & 139 & Upper Oligocene & $\begin{array}{l}\text { Brown-yellow nannoplankton } \\
\text { ooze, with radiolarians }\end{array}$ & 19.3 & 68 & 2.3 & 765 & 755 & 140 & 1.89 & 1.10 \\
\hline $59.1-3-3$ & 55 & Quaternary & $\begin{array}{l}\text { Dark yellow-brown zeolitic } \\
\text { clay }\end{array}$ & 19.4 & 72 & 5.8 & 910 & 550 & 205 & 2.39 & - \\
\hline $59.2-2-3$ & 103 & Lower Miocene & $\begin{array}{l}\text { Dark yellow-brown siliceous } \\
\text { ooze, clay, ash }\end{array}$ & 19.4 & 72 & 5.0 & 60 & 775 & 185 & 2.24 & 2.53 \\
\hline $60.0-1-1$ & 53 & Upper Middle Miocene & Banded yellow-brown volcanic sand & 19.6 & 66 & 3.4 & 500 & 725 & 190 & 1.89 & 1.57 \\
\hline Seawater & 0 & (Goldberg, 1965) & & 19.0 & 65 & 4.6 & 2 & 10 & 170 & 2.7 & 2.7 \\
\hline
\end{tabular}

${ }^{a}$ Sample number refers to hole, core and section. Location of holes, water depth, etc. can be found elsewhere in this volume.

Depth refers to depth below sediment-water interface.

Data from shipboard gas chromatography using 0.2 milliliter aliquots of sample. 
TABLE 2

Trace Constituents of Interstitial Water, Leg 6, from Large Volume (100 ml) Squeezing

\begin{tabular}{lcccccc}
\hline $\begin{array}{c}\text { Sample } \\
\text { Designation }\end{array}$ & $\begin{array}{c}\text { Depth Below } \\
\text { Sea Bed } \\
(\mathrm{m})\end{array}$ & $\begin{array}{c}\mathrm{Fe} \\
(\mu \mathrm{g} / \mathrm{kg})\end{array}$ & $\begin{array}{c}\mathrm{Co} \\
(\mu \mathrm{g} / \mathrm{kg})\end{array}$ & $\begin{array}{c}\mathrm{Ni} \\
(\mu \mathrm{g} / \mathrm{kg})\end{array}$ & $\begin{array}{c}\mathrm{Cu} \\
(\mu \mathrm{g} / \mathrm{kg})\end{array}$ & $\begin{array}{c}\mathrm{Si}^{\mathrm{a}} \\
(\mathrm{mg} / \mathrm{kg})\end{array}$ \\
\hline $47.2-10-5$ & 98 & 28 & 2.6 & 22 & 35 & 9.2 \\
$50.1-1-2$ & 6 & 20 & 1.3 & 8 & 27 & 6.1 \\
$53.2-1-5$ & 20 & 20 & 2.9 & 14 & 19 & 14.5 \\
$55.0-10-5$ & 89 & 16 & 1.0 & 8 & 20 & 20.6 \\
Seawater & 0 & 10 & 0.1 & 2 & 3 & 3.0 \\
\hline
\end{tabular}

${ }^{\mathrm{a}}$ Separate split of water, kept frozen from time of collection.

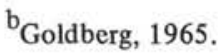

Manganese and zinc concentrations could be determined on nearly all samples without pre-concentration, as has been the case on previous legs. These values are given in Table 1, along with other minor elements which could be similarly determined. The authors again suspect that the zinc concentrations, which are uniformly much higher than sea water values, may be the result of contamination during drilling, squeezing, or storage.

Manganese concentrations are, as has been the case with samples from previous legs, highly variable and independent of location or depth in the sediment column. There are no obvious correlations with sediment type, depth, $\mathrm{Eh}, p \mathrm{H}$ or other variables, with the exception that those white, nearly pure, nannoplankton-foraminiferal oozes all give low manganese concentrations. This did not appear to be the case with the Leg 5 samples, but there the lithologies were less uniform with depth, and vertical migration of manganese could well have obscured any correlations with sediment type. Site 53 appears to give an excellent example of such migration. There, the concentration at 28 meters depth proved to be more than $4 \mathrm{ppm}$, and a uniform decrease in concentration was noted above and below this depth. It is not possible at this time to identify the solid phase or phases which are releasing manganese, but if such a concentration gradient is maintained for even a relatively short time geologically, a significant redistribution of the total manganese in the sediment column will occur.

There is very poor agreement between the boron concentrations given in Table 1 and those determined by Manheim et al. This is rather surprising in view of the fact that the agreement was generally good for the Leg 5 samples. The boron concentrations found here are similar to those found on previous legs. That is, most of the values are somewhat lower than the normal sea water values, but there is considerable variation with location and depth. The authors' data gives no evidence for contribution of boron from depth; rather uptake, probably by clays, seems to be the dominant mechanism at almost every site.

Pore waters have tended to show enrichment in lithium with depth at most sites on previous legs, especially where samples from near the "basement" were recovered. This trend is less pronounced in Leg 6 samples than in samples from previous legs, but samples from Site 53, where a reportable "baked" contact was encountered at depth, do show a significant enrichment in lithium. Several other samples, especially those from Site 54, appear to be slightly depleted in lithium. No explanation can be offered here as to why these sediments, which are largely volcanic ash, should remove lithium from the interstitial water.

Both the chloride and bromide values show slightly more scatter than the authors believe to be real, although, as can be seen, all samples differ very little from average seawater values. It seems likely that there is practically no change in the concentration of either with depth, that is, both are relatively inert to diagenetic changes occurring in the sediment column. Only where there is evidence of evaporites in the column, such as in the Gulf of Mexico, have these two elements shown concentrations significantly different from the overlying seawater in these studies.

The total carbon dioxide values given in the next-tothe-last column of Table 1 were obtained by a manometric measurement of the carbon dioxide evolved 
from an acidified sample of water. The small sample size makes accurate measurement with a conventional manometer difficult, nevertheless there is moderately good agreement between our values and those of Takahashi (this volume) for those samples analyzed by both groups. Most of the values differ by less than 10 per cent, and the differences seem to be random rather than biased one way or the other. The agreement between the authors' laboratory and shipboard measurements is not as good as desired, but generally follows the same trends. Subsequent shipboard analyses are proving to be more reliable, as the techniques improve. Although the data is presented in this report (last column, Table 1) for the sake of completion and comparison, the authors advise that the laboratory data be used for reference and calculation. Despite their confidence in the laboratory data for total dissolved carbon dioxide, they believe that some of the laboratory values may include a small contamination from laboratory air, which was enriched in carbon dioxide due to the large amounts of dry ice used in the laboratory. Very small amounts of this isotopically light carbon dioxide significantly affects the carbon isotope ratios, therefore no isotope data is included in this report. Both the problem of atmospheric contamination and that of measuring very small volumes have now been solved, and it is hoped that future leg reports will be more complete and more reliable.

The outstanding feature of the carbon dioxide distribution in the Leg 6 samples is the extremely low concentrations found at depth at Site 53. A decrease in dissolved carbonate and a resultant decrease in alkalinity was noted at some of the Leg 5 sites, but the decreases were not nearly as pronounced as that at Site 53. Measurements here show about $0.4 \mathrm{~mm} / \mathrm{kg}$ total carbon dioxide at depth, and both Takahashi and the shipboard gas chromatograph found even lower values for these samples.

This remarkable depletion in dissolved carbonate is accompanied by an equally remarkable increase in dissolved calcium, as reported by Manheim (this volume) and confirmed by the authors' own measurements.
There is, in fact, an approximately 7 -fold decrease in dissolved carbonate corresponding to an approximately 7 -fold increase in dissolved calcium. This is exactly what would be expected if the interstitial water is maintaining equilibrium with a solid carbonate phase while the dissolved calcium increases, due to release from some other solid phase.

The calcium increase is balanced by a decrease in dissolved magnesium and potassium, but the exact nature of this "ion exchange" reaction is not clear. Neither is it clear how long such a process has been operating. The very steep concentration gradients now existing would result in a considerable transfer of matter if long maintained. Perhaps much of the re-crystallized calcite reported by shipboard observers (preliminary hole summary) has resulted from seawater carbonate diffusing down through the interstitial water and reacting with calcium leached from volcanic ash. Mag. nesium and potassium could also be supplied by diffusion, ultimately radically altering the nature of the sediments.

\section{REFERENCES}

Brooks, R. R., Presley, B. J. and Kaplan, I. R., 1967. APDC-MIBK extraction system for the determination of trace metals in saline waters by atomic absorption spectrophotometry. Talena. 14, 809.

Goldberg, E. D., 1965. Minor elements in sea water. In Chemical Oceanography. J. P. Riley and G. Skirrow (Eds.). London (Academic Press). 1, 163.

Manheim et al., 1970. Interstitial water studies in small core samples, Deep Sea Drilling Project, Leg 6. In Heezen, B. C. et al., 1970. Initial Reports of the Deep Sea Drilling Project, Volume VI. Washington (U.S. Government Printing Office).

Presley, B. J. and Kaplan, I. R., 1970. Interstitial water chemistry, Deep Sea Drilling Project, Leg 4. In Bader, R. G. et al., 1970, Initial Reports of the Deep Sea Drilling Project, Volume IV. Washington (U.S. Government Printing Office) p. 415. 